\title{
Childhood Leukemia
}

National Cancer Institute

\section{Source}

National Cancer Institute. Childhood Leukemia. NCI Thesaurus. Code C4989.

An acute or chronic leukemia that occurs during childhood. 